\title{
Phenolic compounds removal by grasses and soil bacteria after land application of treated palm oil mill effluent: A pot study
}

\author{
Phongphayboun Phonepaseuth ${ }^{1}$, Viroj Rakkiatsakul ${ }^{1}$, Boonlue Kachenchart ${ }^{2}$, Oramas Suttinun ${ }^{3}$, \\ Ekawan Luepromchai ${ }^{1,4^{+}}$ \\ ${ }^{1}$ Microbial Technology for Marine Pollution Treatment Research Unit, Department of Microbiology, Faculty of Science, Chulalongkorn University, \\ Bangkok, Thailand \\ ${ }^{2}$ Faculty of Environment and Resource Studies, Mahidol University, Nakhon Pathom, Thailand \\ ${ }^{3}$ Environmental Assessment and Technology for Hazardous Waste Management Research Center, Faculty of Environmental Management, Prince of \\ Songkla University, Songkhla, Thailand \\ ${ }^{4}$ Center of Excellence on Hazardous Substance Management, Chulalongkorn University, Bangkok, Thailand
}

\begin{abstract}
Land application of treated palm oil mill effluent (TPOME) could be used as an alternative tertiary wastewater treatment process. However, phenolic compounds in TPOME might be leached to the environment. This study investigated the ability of grasses on reducing phenolic compounds in the leachate after TPOME application. Several pasture grasses in soil pots were compared after irrigating with TPOME from stabilization ponds, which contained 360-630 mg/L phenolic compounds. The number of soil bacteria in planted pots increased over time with the average of $10^{8} \mathrm{CFU} / \mathrm{g}$ for mature grasses, while only $10^{4}-10^{6} \mathrm{CFU} / \mathrm{g}$ were found in the unplanted control pots. The leachates from TPOME irrigated grass pots contained lower amounts of phenolic compounds and had lower phytotoxicity than that of control pots. The phenol removal efficiency of grass pots was ranged 67-93\% and depended on grass cultivars, initial concentration of phenolic compounds and frequency of irrigations. When compared to water irrigation, TPOME led to an increased phenolic compounds accumulation in grass tissues and decreased biomass of Brachiaria hybrid and Brachiaria humidicola but not Panicum maximum. Consequently, the application of TPOME could be conducted on grassland and the grass species should be selected based on the utilization of grass biomass afterward.
\end{abstract}

Keywords: Land application, Palm oil mill effluent, Phenolic compounds, Rhizoremediation, Wastewater treatment

\section{Introduction}

Palm oil mill effluent (POME) is generated at high quantity during palm oil extraction and usually contains high amounts of total solids, oil and grease, COD and BOD [1]. To treat POME, most of palm oil mills in Thailand use anaerobic digestion followed by a series of stabilization ponds, while a few palm oil mills use only stabilization pond system. The effluent from stabilization ponds or treated POME (TPOME) has better water quality but still contains toxic phenolic compounds. Recently, several bacterial and fungal strains have been found to degrade up to $80-90 \%$ of $27-475 \mathrm{mg} / \mathrm{L}$ phenolic compounds in TPOME [2-4]. These microbial strains usually applied as immobilized cells in bioreactor with aeration unit, thus the process construction and operation will be inconvenient and costly. A low cost tertiary wastewater treatment process is therefore required for the TPOME.

The application of natural systems to treat and recycle wastewaters has received wide attention due to their ability to combine the activities of plants, bacteria and environmental media [5]. For agro-industry, land application of wastewater is carried out as a simple and low cost waste disposal strategy as well as for crop fertilization and irrigation [6]. The technique is currently used by olive oil mill [7-8], potato industry [9] and dairy industry [10], however, the wastewater may cause negative impacts to the environment. For example, Steinmetz et al. [7] found that olive mill wastewater (OMW) application
This is an Open Access article distributed under the terms of the Creative Commons Attribution Non-Commercial License (http://creativecommons.org/licenses/by-nc/3.0/) which permits unrestricted non-commercial use, distribution, and reproduction in any medium, provided the original work is properly cited.

Copyright (C) 2019 Korean Society of Environmental Engineers
Received April 12, 2018 Accepted June 23, 2018

${ }^{\dagger}$ Corresponding author

Email: ekawan.1@chula.ac.th

Tel: +662-2185070 Fax: +662-2527576

ORCID: 0000-0001-7740-0211 
increased soil water repellency, phytotoxicity, acidification and groundwater contamination due to the high concentrations of fatty acids and phenolic compounds. Nonetheless, the risk can be minimized by applying OMW in spring or late autumn because of enhanced biodegradation [7]. Di Bene et al. [8] also found short-term negative effects of OMW on soil quality especially the significantly high concentrations of soluble phenols, however these effects do not persist and can be considered negligible after a suitable waiting period. The similar characteristics of OMW and POME suggested that the leaching of phenolic compounds should be of concern as potential pollutants after land application of TPOME.

To reduce the accumulation of phenolic compounds, several researchers investigated the potential of selected plants on directly assimilating and degrading these pollutants and indirectly promoting biodegradation by soil microorganisms. Bodini and Santori [11] reported that perennial tree species such as Cupressus sempervirens and Quercus ilex can reduce more than $90 \%$ phenol by the end of OMW 6-month irrigation cycle, of which the high efficiency is due to the stimulation of specific microbial populations in rhizosphere soil. Besides trees, grasses have been reported for the ability to detoxify phenol, for example, Vetiveria zizanioides (L.) Nash along with their rhizosphere bacteria can degrade $500 \mathrm{mg} / \mathrm{L}$ phenol in illegal dumped industrial wastewater after growing on a floating platform in aerated tank [12]. There is no report on phenol degradation by grassland. However, Szuba et al. [9] studied the effect of 40-year irrigation of potato industry wastewater on a grassland by monitoring the stress conditions of poplars that used for afforestation and found no apparent plant stress. The above researches suggested that grass has high potential for reducing phenolic compounds and other negative impacts from the land application of wastewater.

The objective of this study was to investigate the ability of pasture grasses and soil bacteria to reduce phenolic compounds in the leachate after TPOME application. Several grasses such as Brachiaria spp. (Signal grass), Brachiaria hybrid (Mulato II grass) and Panicum maximum Jacq (Guinea grass) were compared by growing in soil pots and irrigating with TPOME from stabilization ponds at several time points. These grasses are popular in Thailand for forage production and can be grown on acidic and infertile soil [13]. Plant roots release various kind of organic compounds such as amino and fatty acids, carbohydrates, vitamins, nucleotides, polysaccharides, proteins and phenolic compounds, which can influence the microbial community structure and pollutant-degrading activity in the rhizosphere [14]. Nonetheless, plant selection is crucial for the success of rhizoremediation because root exudate compounds from certain plant species have specific impact on microbial communities [15]. It is thus possible to select specific grass for TPOME land treatment and to use their biomass to provide some monetary values.

\section{Materials and Methods}

\subsection{Grass Cultivars, Wastewater and Soil}

In the preliminary study and phase 1 experiment, three
Brachiaria spp. including $B$. brizentha, $B$. decumbens and $B$. humidicola were obtained as stolons from the Lampang Animal Nutrition Research and Development Center, Thailand. In phase 2 experiment, seeds of Brachiaria hybrid (B. ruziziensis $\times B$. Decumbens $\times B$. brizantha) and Panicum maximum Jacq were provided by Michael Hare, Ubon Ratchathani University, while $B$. humidicola stolons were obtained from the Suratthani Animal Nutrition Research and Development Center. The grass seeds and stolon were grown under greenhouse condition.

TPOME samples were collected from the two last stabilization ponds $\left(10^{\text {th }}\right.$ and $11^{\text {th }}$ ponds) of a medium-scale palm oil mill in Surat Thani province, Thailand. The samples were stored in $20 \mathrm{~L}$ bottles and kept at $4^{\circ} \mathrm{C}$ prior to use. The maximum storage time was 2 weeks. The TPOME had dark brown color and contained 360-630 mg/L phenolic compounds. Top soil sample was excavated $(0-15 \mathrm{~cm}$ depth) from a planting area at the palm oil mill and was screened through a $2 \mathrm{~mm}$ mesh to separate slivers and grains. The soil was loamy sand with 83.8\% sand, $12.3 \%$ silt and $3.9 \%$ clay and initial $\mathrm{pH} 7.8$.

\subsection{Experimental Design}

The preliminary study was conducted to examine the ability of Brachiaria spp. to promote the growth of phenol-degrading bacteria in soil. The 14-d old grass was transferred into a 2.5 $\mathrm{kg}$ soil pot at 3 plantlets/pot and cultivated for $60 \mathrm{~d}$ in the greenhouse (Fig. 1(a), (b) and (c)). A moisture block was inserted in middle of each pot for measuring soil moisture and calculating water holding capacity of the soil. The grass pots were irrigated with tap water every 3 days to maintain the water content at $60 \%$ of water holding capacity (WHC). The control soil was an irrigated pot without grass. Soil sampling was carried out by inserting a plastic straw $(25.4 \mathrm{~cm} 1.27 \mathrm{~cm})$ into the pot and collecting the soil at $5 \mathrm{~cm}$ depth from the soil surface every $10 \mathrm{~d}$ to determine the number of phenol-degrading bacteria.

The TPOME application experiments were divided into 2 phases to evaluate the ability of grasses to reduce phenolic compounds and to determine the factors influencing TPOME treatment process. All of the tested grasses were grown in an evaporative cooling greenhouse for $30 \mathrm{~d}$ and each experiment was carried out in triplicates. The greenhouse conditions were $28-30^{\circ} \mathrm{C}$ daytime and $24-26^{\circ} \mathrm{C}$ nighttime temperatures, $60-70 \%$ relative humidity and 8 -hr photoperiod to represent the tropical climate. In phase $1, B$. humidicola was grown in a soil pot at 5, 10 and 20 plantlets/pot (Fig. 2(a), (b) and (c)). Each pot was irrigated with $200 \mathrm{~mL}$ TPOME from the second to last stabilization pond ( $10^{\text {th }}$ pond), incubated for $3 \mathrm{~d}$, flushed with $600 \mathrm{~mL}$ tap water and dried the soil for $3 \mathrm{~d}$. The procedure was considered as 1 irrigation cycle, while the soil moisture content was averaged $60 \%$ WHC. The experiment was carried out for $60 \mathrm{~d}$ with the total of 10 irrigation cycles. The remaining phenolic compounds in the leachate was analyzed and compared with those from the unplanted control soil pots. The growth of soil bacteria and grass was determined every $20 \mathrm{~d}$.

In phase 2, soil pots contained $B$. humidicola, Brachiaria hybrid and $P$. maximum Jacq were compared after irrigating 
with TPOME from the last stabilization pond ( $11^{\text {th }}$ pond) (Fig. 4). Since the concentration of phenolic compounds was lower that phase 1, TPOME was applied every other day (3 times a week) and the total volume was kept below 60\% WHC of the soil pot. At the end of each week, the pot was flushed with $600 \mathrm{~mL}$ tap water to collect the leachate. The irrigation was continued for 5 weeks without allowing the soil to dry out. Consequently, the volume of added TPOME in each week was reduced over time due to water saturation. In this experiment, the additional grass pots were irrigated with only tap water to determine the effect of TPOME on grass biomass and phenol accumulation. The unplanted control soil pot was also conducted. The plant biomass was collected at the end of experiment.

\subsection{Phenolic Compounds Analyses}

Analysis of total phenolic compounds was modified from Barlocher and Graca [16] using Folin-Ciocalteau method. Briefly, $1 \mathrm{~mL}$ of leachate sample was centrifuged at 10,000 rpm for $10 \mathrm{~min}$ to precipitate the soil particles. The supernatant at $100 \mu \mathrm{L}$ was transferred to a new tube containing $150 \mu \mathrm{L}$ DI water and $1 \mathrm{~mL}$ of $2 \% \mathrm{Na}_{2} \mathrm{CO}_{3}$ was added. After 5-min incubation, $50 \mu \mathrm{L}$ of Folin-Ciocalteau reagent was added and mixed. The sample was incubated for $1 \mathrm{~h}$ at room temperature and measured the absorbance at $760 \mathrm{~nm}$. The total phenolic compounds were determined using gallic acid as a standard. The percent removal of phenolic compounds was calculated from the equation below:

Percent removal $(\%)=$

$\underline{\text { Initial phenolic compounds(mg) - Final Phenolic Compunds(mg) }} \times 100$ Inital phenolic compunds(mg)

Where the initial phenolic compounds were the total mass of phenol in TPOME used for irrigation and the final phenolic compounds were the total mass of phenol in the leachate collected over time. Mass of phenolic compounds (mg) was calculated from the concentration in the leachate $(\mathrm{mg} / \mathrm{L})$ times the leaching volume $(\mathrm{mL})$.

The concentration of phenolic compounds in each part of grasses was determined after extraction by a method modified from Hancock and Dean [17]. Briefly, $10 \mathrm{~mL}$ of methanol/water $(60 / 40 \mathrm{v} / \mathrm{v})$ was added to one gram of ground sample. The homogenate was mixed and sonicated for $1 \mathrm{~h}$. The mixed samples were centrifuged at $10,000 \mathrm{rpm}$ for $10 \mathrm{~min}$ and the supernatant was analyzed for a total phenolic compounds by Folin-Ciocalteau method.

\subsection{Phenol-degrading Bacteria, Grass and Phytotoxicity Analyses}

The number of phenol-degrading bacteria in the preliminary study and phase 1 experiment was measured by most probable number (MPN) technique with phenol as sole carbon source. Briefly, the soil sample was diluted in carbon free mineral medium (CFMM) prepared as in Klankeo et al. [18]. Then, the diluted samples were added to CFMM plus $50 \mathrm{mg} / \mathrm{L}$ phenol in microtiter plate. The growth of bacteria was measured from turbidity at $\mathrm{OD}_{450}$ after 14-d incubation. In phase 2, the phenol-degrading bacteria were counted by the spread plate method using CFMM agar plus $100 \mathrm{mg} / \mathrm{L}$ phenol. The agar plates were incubated for $5 \mathrm{~d}$. The spread plate technique was used because it had shorter incubation time than the MPN technique in the phase 1 experiment. However, the bacterial numbers from spread plate technique might not include the slow growth bacteria. To avoid the discrepancy between these two techniques, the data of bacterial numbers were only compared within the same experiment.

The plant growth was measured by determining shoot length and biomass. The shoot length was measured from the above ground parts in soil pot. For biomass dry weight, the grasses were collected at the end of experiment and washed to remove soil particles. Then, they were separated between leaves, stem and roots. The biomass was dried at room temperature about 7-10 d before measuring the dry weight.

Phytotoxicity of leachates was determined by germination index of mungbean (Vigna radiata (L) Wilczek) and cucumber (Cucumis sativus L.var). These common vegetable seeds are sensitive to organic and inorganic pollutants [19-20]. The experiments were conducted in triplicates by placing ten seeds on a Petri dish and adding $5 \mathrm{~mL}$ leachate daily. After $4 \mathrm{~d}$, percent of germination index (GI \%) were calculated according to the following formula:

$$
\mathrm{GI} \%=(\mathrm{Gt} \times \mathrm{Lt}) /(\mathrm{Gc} \times \mathrm{Lc}) \times 100
$$

Where Gt is the mean number of germinated seeds in the treatment sample, $L t$ is the mean root length of the treatment sample, $G c$ is the mean number of germinated seeds in the control (DI water), and $L C$ is the mean root length of the control [21].

\section{Results and Discussion}

\subsection{Growth of Phenol-degrading Bacteria in the Soil Pots with Brachiaria Grasses}

The soil pots with Brachiaria grasses had increasing bacterial number after cultivation. The initial concentration of phenol-degrading bacteria in soil was $3.1 \times 10^{2} \mathrm{MPN} / \mathrm{g}$ soil (Fig. $1(d))$. On day 60 after incubation, the grass pots contained phenol-degrading bacteria at the average of $1.6 \times 10^{5} \mathrm{MPN} / \mathrm{g}$ soil, which was around one order of magnitude higher than the pots without grass at the same period (Fig. 1(d)). Various plant and grass species have been found to release 0.5-11.1 $\mathrm{mg} / \mathrm{L}$ phenolic compounds from their roots during cultivation [22]. Some phenolic compounds are beneficial for plant growth, for example $B$. humidicola roots produce two methylated phenolic acids including methyl-p-coumarate and methyl ferulate that have nitrification inhibitory effects and lead to low nitrification rates in soils [23]. Plant tissues also contain phenolic compounds and $B$. brizantha has been found to contain higher phenolic compounds than P. maximum and Amaranthus hybridus [24]. It was therefore possible that Brachiaria grasses 

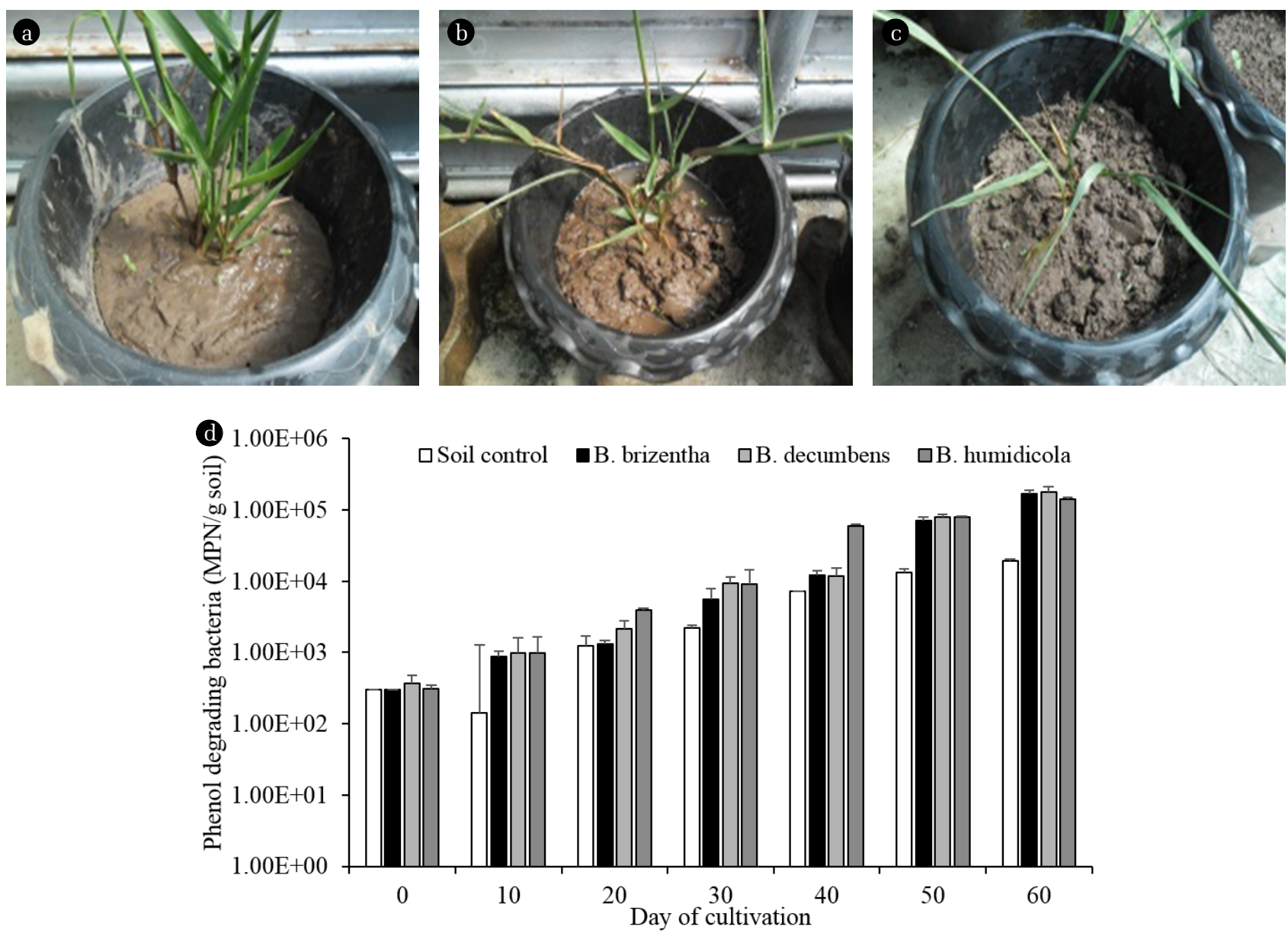

Fig. 1. Three brachiaria grasses including Brachiaria brizantha (a), B. decumbens (b) and B. humidicola (c) were initially grown as plantlets in pots irrigated with tap water. The number of phenol degrading bacteria in the soil was investigated during 60-d cultivation (d).

released phenolic compounds in the rhizosphere and thereby enhanced the growth of phenol-degrading bacteria in the grass pots. When compared between Brachiaria species, the bacterial numbers were not much different at the end of study (Fig. 1(d)). However, B. humidicola had slightly higher bacterial number than other grasses during 20-40 d of cultivation so it was selected for further study.

\subsection{Efficiency of $B$. humidicola on Reducing Phenolic Compounds in Leachates}

When more plantlets of $B$. humidicola were applied to soil pots, more roots and root exudates were expected. This could lead to the higher number of phenol-degrading bacteria and phenol removal efficiency. However, the results from phase 1 experiment showed that the effect of plantlet number on phenol removal efficiencies was minimal. The plant growth and phenolic compounds in leachates from grass pots with 5, 10 and 20 plantlets/pot after each TPOME irrigation cycle were almost similar throughout the study (Fig. 2). The concentrations of phenolic compounds in leachates from grass pots were maintained at below $10 \mathrm{mg} / \mathrm{L}$ during the first 3 irrigation cycles, while the leachates from control soil pots increased from 55 to $82 \mathrm{mg} / \mathrm{L}$ phenolic compounds (Fig. 2(d)). After 10 irrigation cycles (60 d), the concentrations of phenolic compounds in the leachates from all grass pots were increased to an average of $110 \mathrm{mg} / \mathrm{L}$, where there was $242 \mathrm{mg} / \mathrm{L}$ from soil pots (Fig. 2(d)). The accumulation of phenolic compounds after repeated wastewater irrigation was similar to Steinmetz et al. [7] and Di Bene et al. [8].

Regardless of plantlet number, the grass pots removed around $93 \%$ of the phenolic compounds by the end of the study, which was higher than the control soil pot at $73 \%$ (Table 1). This corresponded to the similar number of phenol degrading bacteria in all grass pots. The soil from $60-\mathrm{d}$ irrigated grass pots contained phenol degrading bacteria $>10^{8} \mathrm{MPN} / \mathrm{g}$, while only $10^{4} \mathrm{MPN} / \mathrm{g}$ were found in the control pots (Fig. 3(a)). The bacterial numbers in this experiment were higher than that of grass pots irrigated with tap water (Fig. 1(d)), which could be due to the increasing cultivation period (total of $90 \mathrm{~d}$ ) and the supplement of phenolic compounds from TPOME. The shoot length of grass in 5 and 10 plantlets/pot was similar, but the pots with 20 plantlets had the shortest grass at all time points 

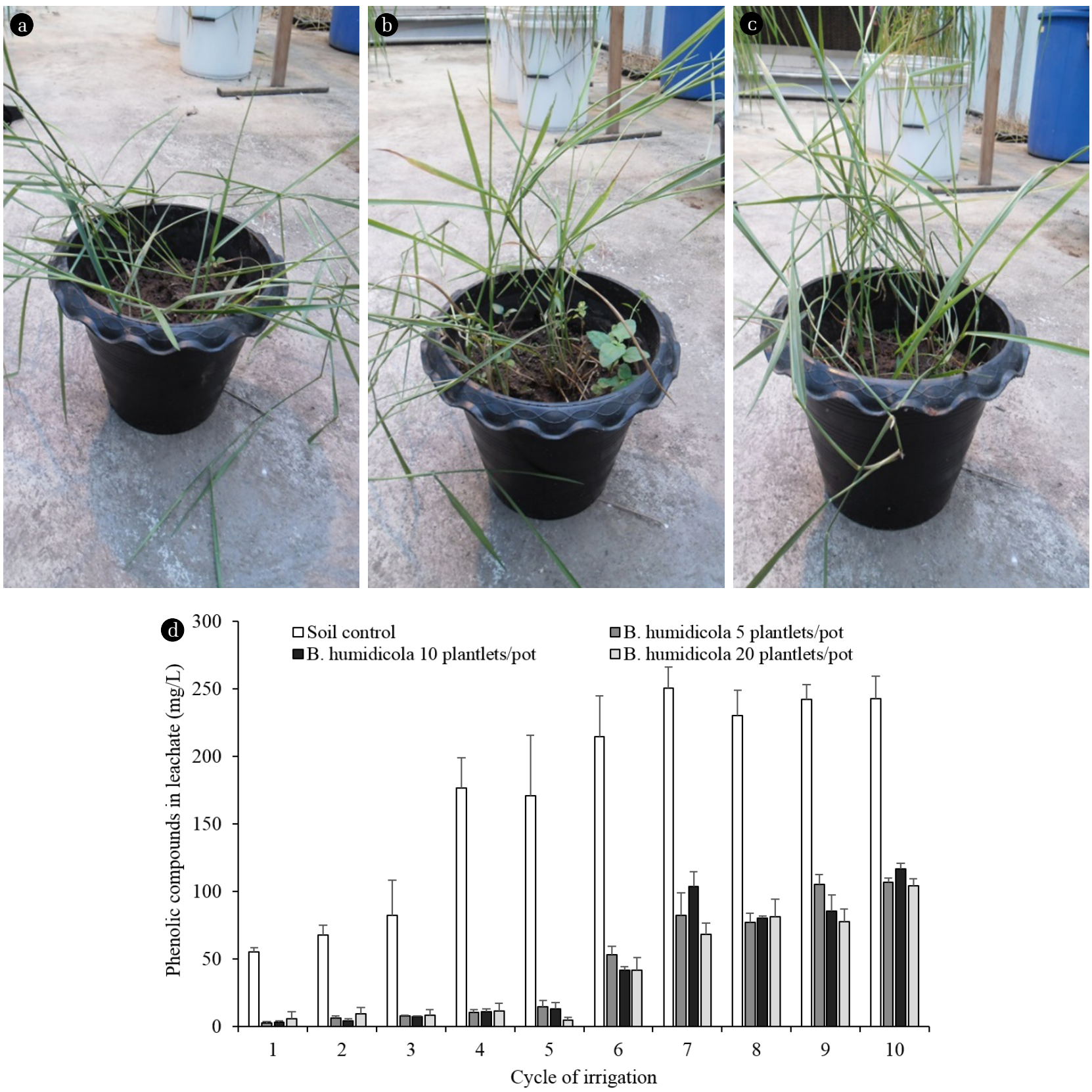

Fig. 2. B. humidicola was grown at 5 (a), 10 (b) and 20 (c) plantlets/pot for $30 \mathrm{~d}$ before irrigating with TPOME in phase 1 experiment. The concentrations of phenolic compounds in leachate were investigated during each 6-d irrigation cycle (d).

(Fig. 3(b)). A competition for limited space probably occurred in grass pots with high plantlet number. The results from phase 1 experiment indicated that the present of $B$. humidicola was necessary for reducing phenolic compounds in TPOME land treatment. However, the grass pot system had a limited capacity for phenol removal. The following phase 2 experiment therefore compared the efficiency of $B$. humidicola with Brachiaria hybrid and $P$. maximum. Brachiaria hybrid has higher yield than $B$. humidicola [13], while $P$. maximum is easy to grow and has been used for sewage treatment [25].

\subsection{Comparison of Various Grasses on Reducing Phenolic Compounds in Leachates}

The decreasing amounts of phenolic compounds in the leachates from all grass in the phase 2 experiment cultivated with Brachiaria hybrid, B. humidicola and P. maximum at 3 plantlets/pot found that all grass cultivars were grown well after irrigation with TPOME from the last stabilization pond (Fig. 4). Similar to the phase 1 experiment, the TPOME irrigated grass pots had lower amounts of phenolic compounds than that of 
Table 1. Efficiency of Grass Pots on Removal of Phenolic Compounds from TPOME Irrigated Soil at the End of Each Experiment

\begin{tabular}{|c|c|c|}
\hline Treatment & Total phenolic compound in leachate (mg) & Phenol removal efficiency of the system (\%)* \\
\hline \multicolumn{3}{|l|}{ Phase $1^{*}$} \\
\hline Soil control & 346 & 72.5 \\
\hline \multicolumn{3}{|l|}{ B. humidicola } \\
\hline 5 plantlets/pot & 93.0 & 92.6 \\
\hline 10 plantlets/pot & 93.3 & 92.6 \\
\hline 20 plantlets/pot & 82.4 & 93.4 \\
\hline \multicolumn{3}{|l|}{ Phase $2^{* *}$} \\
\hline Soil control & 403.0 & 57.7 \\
\hline Brachiaria hybrid & 313.2 & 67.1 \\
\hline B. humidicola & 309.7 & 67.5 \\
\hline P. maximum & 240.1 & 74.8 \\
\hline
\end{tabular}

* Phase 1 experiment added 1,260 mg phenolic compounds into the pots after $60 \mathrm{~d}$.

**Phase 2 experiment added $952 \mathrm{mg}$ phenolic compounds into the pots after $35 \mathrm{~d}$.

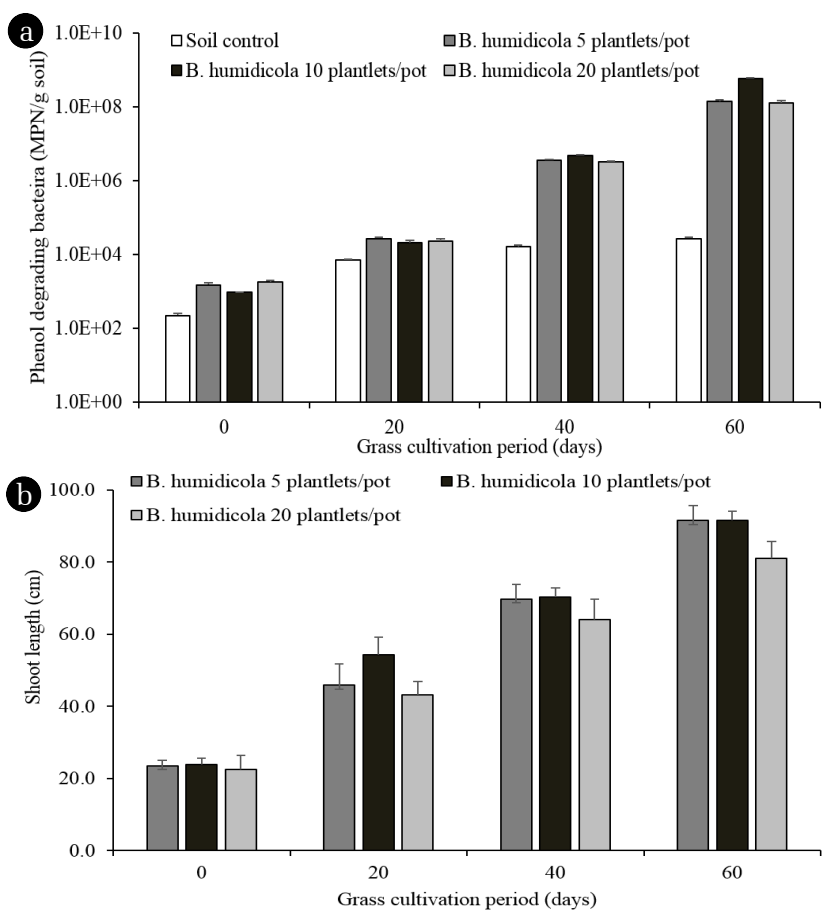

Fig. 3. The number of phenol degrading bacteria in the soil (a) and the shoot length of $B$. humidicola (b) after irrigated with TPOME in phase 1 experiment. At day 60, the TPOME irrigation was carried out for 10 cycles.

soil pots in all sampling points (Fig. 5(a)). The removal efficiencies of $B$. humidicola and $P$. maximum were reduced on week 5 as seen from the high amounts of phenolic compounds, while the efficiency of Brachiaria hybrid was almost the same from week 2-5. The amounts of phenolic compounds in grass pots with water irrigation indicated that grass cultivars especially Brachiaria hybrid and $B$. humidicola released phenolic compounds into the soil. However, the phenolic compounds in water irrigated pots was reduced over time, while the TPOME irrigated pots had increased amounts of phenolic compounds in week 5 (Fig. 5(a)). The accumulation of phenolic compounds in TPOME irrigated pots was corresponded with the phytotoxicity test. The germination index of mungbean and cucumber indicated that the leachates from soil pots were more toxic than that from grass pots and the leachates on week 5 were more toxic than that of week 3 (Table 2). When compared among grasses, Brachiaria hybrid and $P$. maximum had high efficiency on reducing the phytotoxicity of leachates from TPOME irrigated soil. Although, phenolic compounds were found in the leachates from water irrigated pots, they did not pose toxic effects to mungbean and cucumber seeds (Table 2). The results suggested that the types of phenolic compounds in TPOME were different from those released from grasses and led to the higher phytotoxicity.

The decreasing amounts of phenolic compounds in the leachates from all grass pots were corresponded with the increasing number of phenol-degrading bacteria in the soil especially from the 1-4 weeks (Fig. 5(a) and (b)). The numbers of phenol degrading bacteria in grass pots with or without TPOME irrigation were not much different when compared at the same sampling week. The results suggested that the bacterial growth was influenced by the grass root exudates more than the nutrients in TPOME. At the end of study, the grass pots removed $67-75 \%$ of phenolic compounds from the added TPOME, while the control soil pots removed 58\% (Table 1). The phenol removal efficiencies in phase 2 experiment from both grass and soil pots were lower than that of phase 1 experiment (Table 1). The results indicated that phenol accumulation at the end of treatment could be due to the extensive application of TPOME. Phase 2 experiment applied POME every other day with the total added phenolic compounds of $952 \mathrm{mg}$ in 35 days, thus phenol degradation could be limited by the short incubation period before the next irrigation cycle. Consequently, the irrigation of TPOME should be optimized 

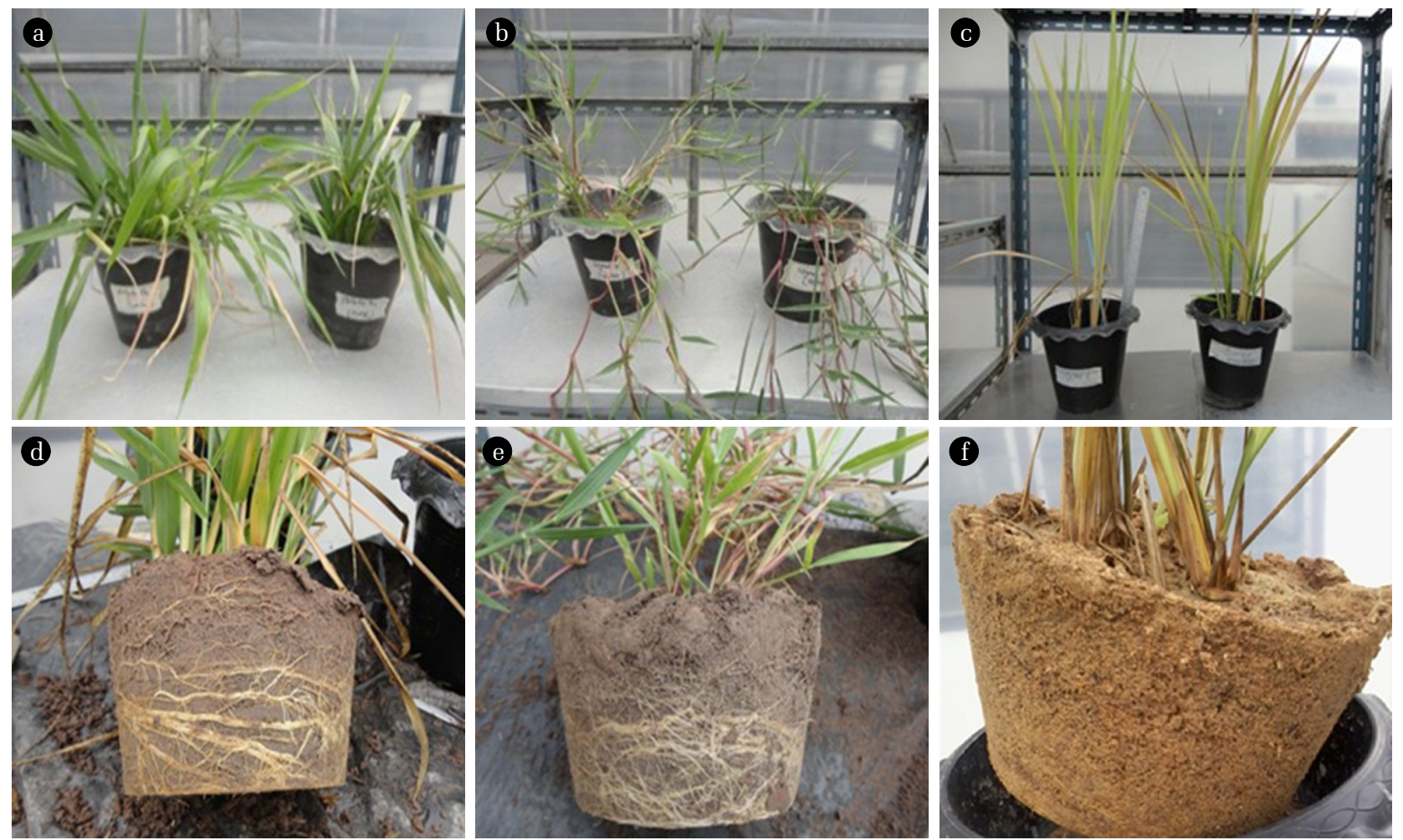

Fig. 4. Brachiaria hybrid (a, d), B. humidicola (b, e) and P. maximum (c, f) grown in pots irrigated with TPOME from the last stabilization pond for 5 weeks in phase 2 experiment.

Table 2. Phytotoxicity of the Leachates from Phase 2 Experiment As Determined by Germination Index of Mungbean and Cucumber

\begin{tabular}{|c|c|c|c|c|}
\hline \multirow{3}{*}{ Treatments } & \multicolumn{4}{|c|}{ Germination index $(\%)^{*}$} \\
\hline & \multicolumn{2}{|c|}{ Third week leachate } & \multicolumn{2}{|c|}{ Fifth week leachate } \\
\hline & Mungbean & Cucumber & Mungbean & Cucumber \\
\hline Soil control (TPOME) & $31.0 \pm 4.3$ & $24.7 \pm 2.8$ & $0.0 \pm 0.0$ & $0.0 \pm 0.0$ \\
\hline Brachiaria hybrid (TPOME) & $59.5 \pm 2.9$ & $51.5 \pm 2.5$ & $64.5 \pm 3.5$ & $60.0 \pm 3.9$ \\
\hline B. humidicola (TPOME) & $44.0 \pm 4.3$ & $40.2 \pm 2.3$ & $9.2 \pm 2.2$ & $0.0 \pm 0.0$ \\
\hline P. maximum (TPOME) & $51.2 \pm 2.9$ & $44.3 \pm 1.9$ & $52.6 \pm 2.0$ & $50.0 \pm 2.5$ \\
\hline Brachiaria hybrid (Water) & $79.8 \pm 0.8$ & $83.5 \pm 2.6$ & $92.1 \pm 4.3$ & $87.5 \pm 4.2$ \\
\hline B. humidicola (Water) & $69.0 \pm 1.3$ & $60.8 \pm 3.7$ & $75.0 \pm 4.8$ & $71.3 \pm 3.7$ \\
\hline P. maximum (Water) & $79.3 \pm 1.1$ & $83.5 \pm 0.9$ & $85.3 \pm 2.9$ & $75.0 \pm 3.7$ \\
\hline
\end{tabular}

*Sample with germination index more than $50 \%$ was considered non-toxic [21]. In this study, the germination index of mungbean and cucumber with TPOME from the last stabilization pond were averaged 25.5 and 17.9\%, respectively.

to promote the activity of grass and their soil-associated bacteria. Embrandiri et al. [26] also recommended that the rates for land application of palm oil mill waste should be in a scientific manner and specific for targeted plant species on the land. Another approach to reduce phenol accumulation is to add effective phenol-degrading bacteria such as Methylobacterium sp. NP3 and Acinetobacter sp. PK1 [2, 27] or fungi such as Trametes hirsuta AK04 [3] and Pleurotus sajor caju [28] in the grass-soil pots to support the activity of soil bacteria.

\subsection{Phenol Accumulations and Yields of Grasses after POME Irrigation}

$P$. maximum had the highest efficiency phenol removal efficiency when compared between grass cultivars (Table 1). However, the number of phenol-degrading bacteria in pots containing $P$. maximum was similar to other grasses after 4 weeks (Fig. 5(b)). In addition to enhance bacterial growth, Phenrat et al. [12] reported that the activity of grass on phenol degradation involves phytopolymerization and phyto-oxidation 

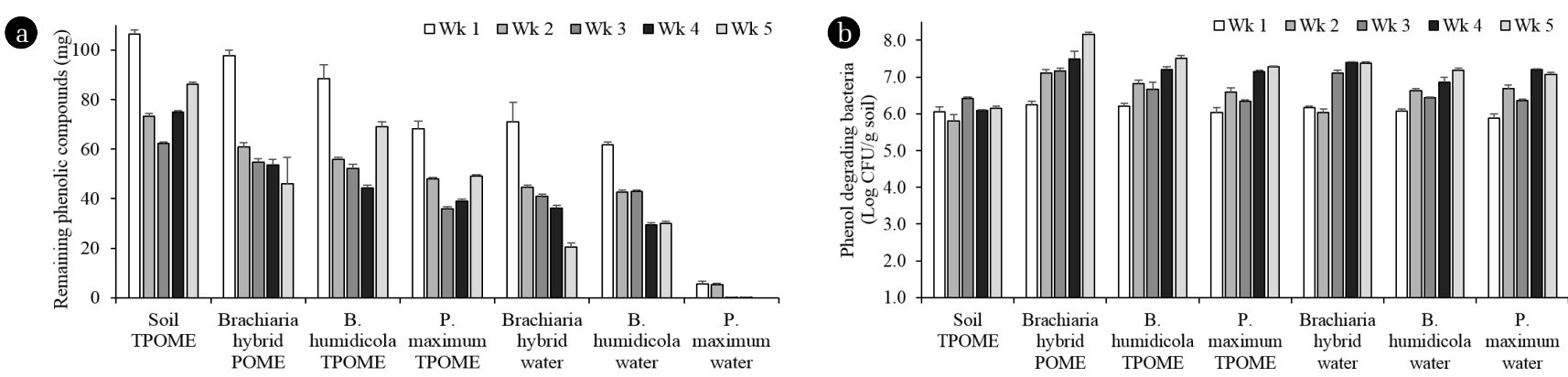

Fig. 5. The amounts of phenolic compounds in leachate (a) and numbers of phenol degrading bacteria in the soil (b) of Brachiaria hybrid, $B$. humidicola and P. maximum pots irrigated with TPOME in phase 2 experiment.
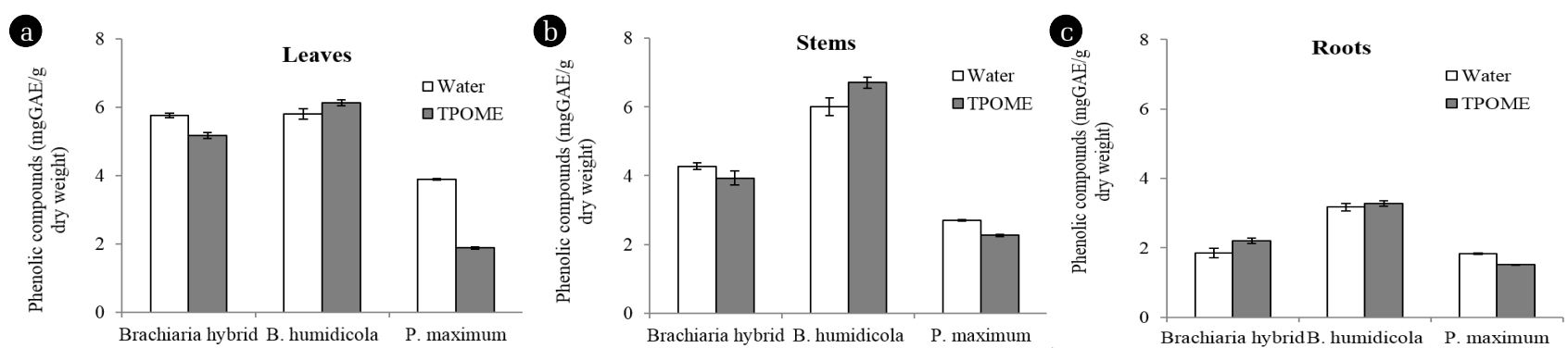

Fig. 6. The concentrations of phenolic compounds in leaves (a) stems (b) and roots (c) of Brachiaria hybrid, B. humidicola and P. maximum irrigated with TPOME in phase 2 experiment.
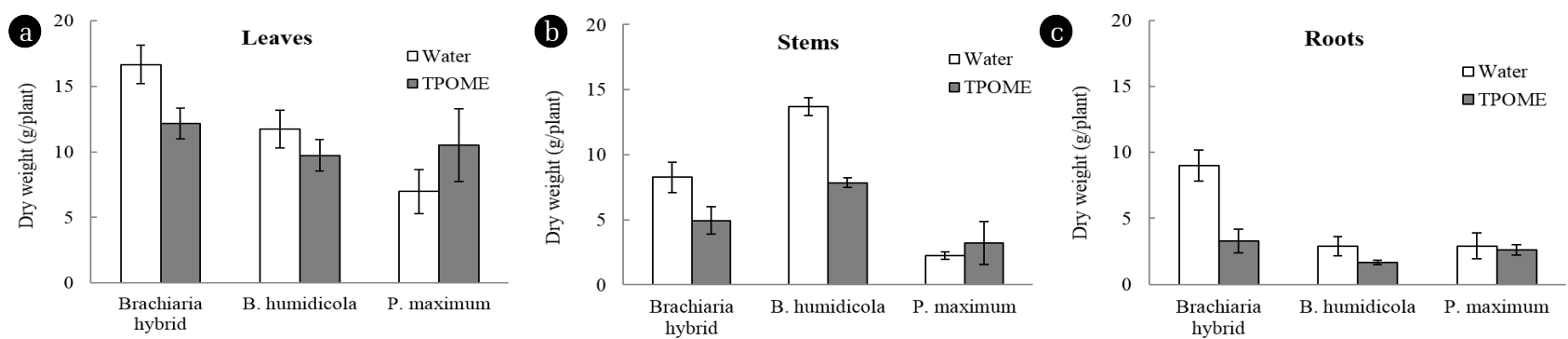

Fig. 7. The leaves (a) stems (b) and roots (c) dry weight of Brachiaria hybrid, B. humidicola and P. maximum irrigated with TPOME in phase 2 experiment.

assisted by root-produced peroxide and peroxidase. It was thus possible that $P$. maximum could produce and release some enzymes to reduce phenolic compounds. The accumulation of phenolic compounds in leaves, stems and roots of P. maximum was lower than Brachiaria hybrid and B. humidicola regardless of TPOME or water irrigation (Fig. 6). In addition, the amounts of phenolic compounds in leachates from $P$. maximum pots with water irrigation were almost undetectable at all time points (Fig. 5(a)). The results suggested that $P$. maximum itself had mechanisms for reducing phenolic compounds and should be investigated further. Besides growing $P$. maximum in soil, it can be cultivated as constructed wetland, of which the wastewater can be supplied via subsurface flow [25].

The dry weight of $P$. maximum leaves, stems and roots after TPOME and water irrigation was not much different, while Brachiaria hybrid and $B$. humidicola had lower bio- mass in the presence of TPOME (Fig. 7). The low toxicity effect of TPOME and low phenolic compound accumulation suggested that TPOME could be utilized as water and nutrient sources for $P$. maximum and later for animal feed production. On the other hand, the phenolic compounds in Brachiaria hybrid and $B$. humidicola tissues might be beneficial as natural antioxidants. Chitindingu et al. [24] reported that methanolic extract solutions from grains of $B$. brizantha and P. maximum had phenolic compounds and antioxidant properties, which can be used for drug development.

\section{Conclusions}

All of the tested grasses were able to reduce the phenolic compounds in leachates after TPOME irrigation in soil pots. The cultivation of grasses promoted the growth of phenol-degrading 
bacteria regardless of TPOME or water irrigations. The extent of phenol removal was found to depend on grass cultivars, amount of added phenolic compounds and frequency of irrigations. The grass with high efficiency i.e. $P$. maximum had low phenolic compound accumulation, thus suggested that the grass itself along with their soil-associated bacteria responsible for phenolic compound degradation. To promote the continuous reduction of phenolic compounds, the irrigated soil should be dried out to enhance aerobic phenol degradation. $P$. maximum may be used as animal feeds afterward. Other grasses had lower efficiency and slightly accumulated phenolic compounds in their tissues. They could be used for extraction of bioactive compounds. In summary, the TPOME application on grassland could be used as a tertiary wastewater treatment and the field investigation of this process is recommended.

\section{Acknowledgments}

This research was supported by grants from the Agricultural Research Development Agency (Public Organization), the Chulalongkorn University Graduate Scholarship to Commemorate the $72^{\text {nd }}$ Anniversary of His Majesty King Bhumibol Adulyadej and the Scholarship Program for ASEAN Countries, Chulalongkorn University.

\section{References}

1. Singh RP, Ibrahim MH, Esa N, Iliyana MS. Composting of waste from palm oil mill: A sustainable waste management practice. Rev. Environ. Sci. Biotechnol. 2010;9:331-344.

2. Khongkhaem P, Suttinun O, Intasiri A, Pinyakong O, Luepromchai E. Degradation of phenolic compounds in palm oil mill effluent by silica-immobilized bacteria in internal loop airlift bioreactors. Clean-Soil Air Water 2016;44: 383-392.

3. Kietkwanboot A, Tran HTY, Suttinun O. Simultaneous dephenolization and decolorization of treated palm oil mill effluent by oil palm fiber-immobilized Trametes hirsuta strain AK 04. Water Air Soil Pollut. 2015;226:345.

4. Limkhuansuwan V, Chaiprasert P. Decolorization of molasses melanoidins and palm oil mill effluent phenolic compounds by fermentative lactic acid bacteria. J. Environ. Sci. 2010;22:1209-1217.

5. Polprasert C, Liamlaem W. A Transdisciplinary Approach for Water Pollution Control: Case Studies on Application of Natural Systems. Environ. Eng. Res. 2014;19:185-195.

6. Arienzo M, Christen EW, Quayle W, Kumar A. A review of the fate of potassium in the soil-plant system after land application of wastewaters. J. Hazard. Mater. 2009;164:415-422.

7. Steinmetz Z, Kurtz MP, Dag A, Zipori I, Schaumann GE. The seasonal influence of olive mill wastewater applications on an orchard soil under semi-arid conditions. J. Plant Nutr. Soil Sci. 2015;178:641-648.

8. Di Bene C, Pellegrino E, Debolini M, Silvestri N, Bonari E. Short- and long-term effects of olive mill wastewater land spreading on soil chemical and biological properties. Soil Biol. Biochem. 2013;56:21-30.

9. Szuba A, Lorenc-Plucinska G. Utilization of proteomics in experimental field conditions - A case study of poplars growing on grassland affected by long-term starch wastewater irrigation. J. Proteomics. 2015;126:200-217.

10. Liu YY, Haynes RJ. Influence of land application of dairy factory effluent on soil nutrient status and the size, activity, composition and catabolic capability of the soil microbial community. Appl. Soil Ecol. 2011;48:133-141.

11. Bodini SF, Cicalini AR, Santori F. Rhizosphere dynamics during phytoremediation of olive mill wastewater. Bioresour. Technol. 2011;102:4383-4389.

12. Phenrat T, Teeratitayangkul P, Prasertsung I, Parichatprecha R, Jitsangiam P, Chomchalow N, Wichai S. Vetiver plantlets in aerated system degrade phenol in illegally dumped industrial wastewater by phytochemical and rhizomicrobial degradation. Environ. Sci. Pollut. Res. 2017;24:13235-13246.

13. Hare M, Tatsapong P, Phengphet S. Herbage yield and quality of Brachiaria cultivars, Paspalum atratum and Panicum maximum in north-east Thailand. Trop. Grassl. 2009;43:65-72.

14. Rohrbacher F, St-Arnaud M. Root exudation: The ecological driver of hydrocarbon rhizoremediation. Agronomy 2016;6:19.

15. Martin BC, George SJ, Price CA, Ryan MH, Tibbett M. The role of root exuded low molecular weight organic anions in facilitating petroleum hydrocarbon degradation: current knowledge and future directions. Sci. Total Environ. 2014;472:642-653.

16. Bärlocher F, Graça MS. Total phenolics. In: Graça MS, Bärlocher F, Gessner M, eds. Methods to study litter decomposition. Springer Netherlands; 2005. p. 97-100.

17. Hancock P, Dean JR. Extraction and fate of phenols in soil. Anal. Commun. 1997;34:377-379.

18. Klankeo P, Nopcharoenkul W, Pinyakong O. Two novel pyrene-degrading Diaphorobacter sp. and Pseudoxanthomonas sp. isolated from soil. J. Biosci. Bioeng. 2009;108:488-495.

19. Lin D, Xing B. Phytotoxicity of nanoparticles: Inhibition of seed germination and root growth. Environ. Pollut. 2007;150:243-250.

20. Nisha P, Sreedevi S. Phytotoxicity of mercury on seed germination in Vigna radiata (L.) Wilczek. In: Binoj Kumar MS, Gopalakrishnan PK, eds. Biodiversity conservation. Scientific Publishers; 2008. p. 227-234.

21. Anastasi A, Parato B, Spina F, Tigini V, Prigione V, Varese GCA. Decolourisation and detoxification in the fungal treatment of textile wastewaters from dyeing processes. New Biotechnol. 2011;29:38-45.

22. Fletcher JS, Hegde RS. Release of phenols by perennial plant roots and their potential importance in bioremediation. Chemosphere 1995;31:3009-3016.

23. Gopalakrishnan S, Watanabe T, Pearse SJ, Ito O, Hossain ZAKM, Subbarao GV. Biological nitrification inhibition by Brachiaria humidicola roots varies with soil type and inhibits nitrifying bacteria, but not other major soil microorganisms. Soil Sci. Plant Nutr. 2009;55:725-733.

24. Chitindingu K, Ndhlala AR, Chapano C, Benhura MA, Muchuweti M. Phenolic compound content, profiles and 
antioxidant activities of Amaranthus hybrids (pigweed), Brachiaria brizantha (Upright Brachiaria) and Panicum maximum (Guinea grass). J. Food Biochem. 2007;31:206-216.

25. Chavan BL, VP Dhulap. Sewage treatment with constructed wetland using Panicum maximum forage grass. J. Environ. Sci. Water Resour. 2012:1:223-230.

26. Embrandiri A, Singh RP, Ibrahim HM, Ramli AA. Land application of biomass residue generated from palm oil processing: Its potential benefits and threats. Environmentalist
2011;32:111-117.

27. Tosu P, Luepromchai E, Suttinun O. Activation and immobilization of phenol-degrading bacteria on oil palm residues for enhancing phenols degradation in treated palm oil mill effluent. Environ. Eng. Res. 2015;20:141-148.

28. Justino C, Marques AG, Duarte KR, et al. Degradation of phenols in olive oil mill wastewater by biological, enzymatic, and photo-Fenton oxidation. Environ. Sci. Poll. Res. 2010;17:650-656. 